\title{
Reciprocal intercompatibility between Byrsonima Rich. exKunth species (Malpighiaceae), in an urban ecotonal fragment of Semi-Deciduous Seasonal Forest and Cerrado
}

Frederic Mendes Hughes

Instituto Nacional da Mata Atlântica - INMA, Av. José Ruschi, nº 4, Santa Teresa - ES - Brazil, Zip code: 29.650-000

Correspondence

F.M. Hughes

E-mail: fredericmhughes@gmail.com

Received: 29 October 2021

Accepted: 3 November 2021

Published on-line: 22 December 2021

\section{Resumen}

Intercompatibilidad recíproca entre especies de Byrsonima Rich. ex Kunth (Malpighiaceae), en un fragmento ecotonal urbano de Bosque Estacional Semi-Caducifolio y Cerrado

Las especies de Byrsonima presentan monomorfismo floral y comparten gremio de visitantes/polinizadores. Estos rasgos sugieren la evaluación de hipótesis de interincompatibilidad recíproca entre dos especies sintópicas de Byrsonima: $B$. pachyphylla y $B$. crassifolia. Se observó el crecimiento del tubo polínico con comportamiento similar en la superficie estigmática, canal del pistilo, ovario y canal micropilar de ambas especies. Además, se describió la autoincompatibilidad parcial en la autopolinización con mayor fructificación en la autogamia. La polinización cruzada y la autopolinización coexisten y se produce una intercompatibilidad recíproca. Los mecanismos de aislamiento precigóticos son improbables por la ausencia de tubos polínicos anormales, producción de frutos y ausencia de híbridos en la área de estudio.

Palabras clave: Epifluorescencia; Sistema de apareamiento; Abejas recolectoras de aceite; Crecimiento del tubo polínico; Autocompatibilidad.

\begin{abstract}
Byrsonima species present floral monomorphism and sharing visitor/pollinator guild. These traits suggest the hypothesis evaluation of reciprocal inter-incompatibility between two syntopic Byrsonima species: $B$. pachyphylla and $B$. crassifolia. Pollen tube growth with similar behavior was observed in the stigmatic surface, pistil canal, ovary and micropylar channel to both species. In addition, partial self-incompatibility in self-pollination with greater fruiting in autogamy was observed. Cross-pollination and selfpollination coexist, and reciprocal intercompatibility occurs. Prezygotic isolation mechanisms are unlikely by the absence of abnormal pollen tubes, higher fruiting production and absence of hybrids in the study site.
\end{abstract}

Key words: Epifluorescence; Mating system; Oil-collecting bees; Pollen tube growth; Self-compatibility. 


\section{Introduction}

Malpighiaceae is a monophyletic taxon of tropical and subtropical eudicotyledons, phylogenetically related to self-incompatible families, presenting ancestral homomorphic self-incompatibility system and subsequent variation and diversification of lineages with different mating systems (Igic et al. 2008, Davis \& Anderson 2010, Barret 2013). Such evidence supports mating systems variation within and among recognized genera in Malpighiaceae (Anderson 1980, Barros 1992, Sigrist \& Sazima 2004, Benezar \& Pessoni 2006, Costa et al. 2006, Bezerra et al. 2009, Sazan et al. 2014). The floral morphology of the Malpighiaceae is homogeneous, with preferentially co-sexual flowers, gathered in paniculate inflorescences, diurnal anthesis and calyx glands or elaiophores - traits indicative of mellitophily (Vogel 1974, Anderson 1979).

Oil plants and oil-collecting bees are important animal-plant interaction from Neotropical dry forests and savanna (e.g., Cerrado vegetation from Brazil) (Buchmann 1987, Aguiar et al. 2020). Three restricted tribes of female oil-collecting bees (i.e., Centridini, Tapinotaspidini, and Tetrapediini), represented by Centris, Epicharis, and Monoeca, are pollinators of Malpighiaceae (Neff \& Simpson 1981, Sigrist \& Sazima 2004). These bees collected oil for larval provisioning and nest construction (Vogel 1988). Byrsonima, the largest genus of Malpighiaceae in the Neotropic (Cronquist 1981, Davis \& Anderson 2010, Flora do Brasil 2020), exhibit floral monomorphism and is dependent of oil-collecting bees to pollination (e.g., Gottsberger 1986, Barros 1992, Teixeira \& Machado 2000, Benezar \& Pessoni 2006, Costa et al. 2006, Amorim \& de Marco 2011). In addition, Byrsonima species also exhibit a complex nature of self-recognition systems, with self-incompatibility and self-compatibility observed among species and populations. For example, self-incompatibility has been observed in six species (e.g., Byrsonima sericea DC., Teixeira \& Machado 2000 and Matallana et al. 2016, B. microphylla A.Juss., Costa et al. 2006, B. gardneriana A.Juss., Machado et al. 2006 and Bezerra et al. 2009, B. pachyphylla A.Juss., Vilas-Boas et al. 2013, B. umbellate Mart. ex A.Juss., Mendes et al. 2011, and B. lucida (Mill.) DC., Downing \& Liu 2013). On the other hand, self-compatibility has also been commonly observed (e.g., Byrsonima crassi- folia (L.) Kunth, Bawa 1974, B. coccolobifolia Kunth, Benezar \& Pessoni 2006, B. intermedia A.Juss., Oliveira et al. 2007, B. crassa Nied., Peixoto et al. 2011, B. guilleminiana A.Juss., B. laxiflora Griseb., B. subterranean Brade \& Markgr., B. umbellate Mart. ex A.Juss., Barros 1992, and B. basiloba A.Juss., Balestra et al. 2014), and different self-recognition systems have been reported to $B$. intermedia populations (VilasBoas et al. 2013, Balestra et al. 2014).

The labiality of the self-recognition system suggests the possibility of reciprocal intercompatibility or introgression among Byrsonima species. Hitherto, studies evaluating the reciprocal intercompatibility (cross-compatibility) between Byrsonima species are absent, but this phenomenon had already been recognized for different plant species, for example, in Chamaecrista desvauxii (Collad.) Killip. (Costa et al. 2007), Melocactus species (Khan et al. 2020), and commercial fruits (avocado and olive). Byrsonima show floral monomorphism, overlapping of the flowering period, and share pollinators promoting intra- and interspecific pollen flow. These attributes suggest the evaluation of the inter-incompatibility hypothesis between two syntopic populations of Byrsonima pachyphylla and $B$. crassifolia. In addition, a comprehensive dataset of mating systems was building and analyzed to investigate the extent of self-incompatibility mechanisms among Byrsonima species in Neotropics.

\section{Materials and methods}

\section{Study sites and species}

This experimental study was carried out in two syntopic species of Byrsonima in the Ecological Station of the Universidade Federal de Minas Gerais, located in the Belo Horizonte municipality $\left(19^{\circ} 52^{\prime} \mathrm{S}, 43^{\circ} 58^{\prime} \mathrm{W}\right)$, with well-defined dry and wet seasons (Alvares et al. 2013). The urban ecotonal fragment has 102 hectares of area, with vegetation formations of forests of gallery, cerrado and secondary forest. Byrsonima pachyphylla and $B$. crassifolia are small trees and shrubs, respectively (Bawa 1974, Pereira \& Freitas 2002, VilasBoas et al. 2013, Melo et al. 2014). The flower traits of two species are very congruent to the floral display of Malpighiaceae (Vogel 1974, Anderson 1990, Possobom \& Machado 2018): terminal and racemose inflorescences, zygomorphic and 
hermaphroditic flowers, with five pairs of oil glands (elaiophores). All flowers begin yellow, but flowers of B. pachyphylla turn red after first day of flowering (Fig. 1). Mating system treatments were carried out on individuals found in situ over flowering/fruiting season (October 2010 - January 2011, personal observation). Based in the comprehensive dataset building here, the flower season was similar to another population of B. crassifolia (Pereira \& Freitas 2002). However, B. pachyphylla present distinct flowering periods in other populations (e.g., April - July, Vilas-Boas et al. 2013, July and October, Melo et al. 2014). Byrsonima species are visited by oil-collecting bees, and flesh-fruits are globose drupe dispersed by animals (e.g., Amorim \& De Marco 2011, Sazan et al. 2014).

\section{Flowers counting and floral visitors}

The number of flowers per inflorescence was estimate by direct counting of flower buds in 10 inflorescences per species. The change of floral color was verified daily in flowers marked from pollination treatment. Focal observations of floral visitors were performed continuously during one day (07:00 to 17:00 hs) before pollination treatments (November 27, 2010), and not included nocturnal observations. Floral visitors were classified according to Inouye (1980): legitimate (pollinators) or illegitimate (pollen or oil thieves).

\section{Intra- and inter-taxa experimental pollina- tions}

Experimental pollination treatments were used to determine the mating systems and reciprocal intercompatibility between $B$. crassifolia and $B$. pachyphylla. A two-fold approach was followed based on using in vitro (tube pollen growth) and in vivo (fruit:flower set) experimental hand-pollination treatments. Only open flowers of the first day were used, and the number of flowers determined the number of crosses among treatments (981 experimental crosses in 10 individuals of both species, see Table 1 to flowers per treatment and species). Seven pollination treatments on selected flowers in the field were carried out for each approach: (1) pollinator exclusion (inflorescences bagged to exclude pollinators, and flowers not emasculated), (2) self-pollination (flowers bagged and hand-pollinated with pollen from the same flower), (3) "geitonogamy"-pollination (flowers bagged and hand-pollinated with pollen from a different flower on the same plant), (4) cross-pollination (flowers bagged and hand-pollinated with pollen from a flower of a different plant), (5) bidirectional interspecific cross-pollination (flowers bagged and hand-pollinated with pollen from a flower of a different species), (6) apomixis (inflorescences bagged to exclude pollinators), and (7) control (flowers unbagged/open pollination after visitation of bees were marked). To avoid intra-floral interference on cross-pollinated flowers, in other words, the partial contribution of self-pollen grains on tube formation and fruit-set, all flowers of "geitonogamy"-pollination, cross-pollination, bidirectional interspecific cross-pollination and apomixes treatments were emasculated.

To in vitro experiments, flowers were collected 24, 48 and 72 hours after each cross (i.e., six pistils from each treatment, corresponding to 252 flowers in the two species), fixed in FAA-50\% (24 hours) and later transferred to ethanol (70\%). The pistils were placed in $10 \mathrm{~N} \mathrm{NaOH}$ solution $\left(60{ }^{\circ} \mathrm{C}\right.$ for 8 min.), clarified with $\mathrm{NaClO}$ (1 hour), washed in distilled water (3 times) and stained with aniline blue $(0.2 \%)$, squashed on slides to examine pollen tube growth and ovule penetration under epifluorescence microscopy (Martin 1959). Anomalous and normal pollen tubes can be differentiated by the irregular grew on the stylar canal and callose pattern deposition, and/or erratic behavior into the ovary - 'ovarian incompatibility' (Gibbs 2014). In addition, the time-lag of the selfed and crossed pistils (i.e., pollen tubes arrived in the ovary) were investigated in all flowers.

To in vivo experiments, fruit:flower ratio of seven pollination treatments (see above) was quantified after 20 days (immature fruits) of performed experiments (a total of 729 flowers, 52 mean \pm 10 SD by treatments). Abortion of immature fruits used to occur between the 5th and 20th day after pollination, and the maturation time took approximately 120 days. However, fruit was not falling after the 30th day of fruit development, as observed in B. crassifolia (Pereira \& Freitas 2002). In this case, abortion beyond the time slice in this present study was insignificant. Our rationale behind the experimentation of pollinatorexcluded conditions was to assess autonomous/ spontaneous pollination/pollinator independence or apomixis (Sazan et al. 2014). Three indexes were calculated sensu Ruiz-Zapata \& Arroyo (1978) and Lloyd \& Schoen (1992): (i) Self- 
incompatibility index (ISI, \% artificial self-pollination fruits $/ \%$ artificial cross-pollination fruits); (ii) Autogamy index (AI, \% natural self-pollination fruits $/ \%$ natural pollination fruits); and (iii) Reproductive efficacy (RE, \% artificial cross-pollination fruits / $\%$ natural pollination fruits). In detail, the ISI index suggests three classes to species scores: self-compatible (ISI $\geq 0.8$ ), partially $(0.8<\mathrm{ISI}<0.2)$, and self-incompatible (ISI $\leq 0.2)$. In general, ISI and AI values above 0.2 indicated self-compatibility and autogamy (sensu Ruiz-Zapata \& Arroyo 1978, Lloyd \& Schoen 1992). Reproductive efficacy was employed in estimating the performance of the whole pollinator guild (i.e., the pollinators' efficiency to pollen transfer).

The association between responses of fruit set to pollination treatments was calculated using the Chi-square tests for contingency tables (e.g., Bartoš et al. 2020). Chi-square test has low statistical power when used to reduce numbers of expected frequencies between treatments (i.e., probability of rejecting the null hypothesis when indeed this hypothesis is false, Roscoe \& Byars 1971). For circumventing this problem, Fisher's exact test was also conducted because it is not strongest affected by sample size. Similar results were observed between Chi-square and Fisher's test, and hereafter using the Chi-square test $(p<0.05)$. In the same way, differences between species in the reproductive efficacy and Self-Incompatibility index were evaluated in R Program ver. 3.16.1.

\section{Results}

The flowers production during 15 days was simultaneous to B. pachyphylla and B. crassifolia in the study site (Fig. 1). On one hand, flowers of $B$. crassifolia are arranged in dense inflorescences gathering 27-34 flowers per inflorescence, which begin yellow and maintain such color until the senescence. On the other hand, B. pachyphylla produced around 8-12 flowers per inflorescence, which are yellow soon after the flower opening process (during the first day), and turning red (in the second day; Fig. 1a). In both species the flowers were visited by Paratrigona Schwarz, 1938 bees, and by the oil-collecting bees Epicharis (Epicharana) flava Friese, 1900 and Centris (Centris) spilopoda Moure, 1969. The body size and foraging behaviors of oil-collecting bees allowed pollen deposition on the ventral portion of the thorax, performing legitimate visits (Fig. 1c, d). Paratrigona sp. did not contact with the stigma of the flowers and performed illegitimate visits (Fig. 1e). Ectatomma cf. tuberculatum (Olivier, 1792) ants were observed on the inflorescences, supposedly collecting small arthropods (Fig. 1f). The efficacy of oil-collecting bees in the pollen grains transference was confirmed to both species ( $\mathrm{RE} \approx 0.94$ for both species, Table 1 ).

Fruit set differed between all pollination treatments (Table 1). There was no formation of fruits through apomixis in the B. pachyphylla and $B$. crassifolia, but ca. $35.5 \%$ of fruits were formed in pollinator exclusion treatment, and ca. $37 \%$ in artificial self-pollination (Table 1). Geitonogamy treatment in $B$. crassifolia produced more fruits $(58.3 \%)$ than $B$. pachyphylla (45\%). The intraspecific cross-pollination and open pollination produced more fruits in both species when compared with selfing treatments $(\approx 71.75 \%$ fruit set, Table 1). Similar fruiting was formed in inter-taxa pollination in both species ( $>62 \%$, Table 1). Fruit set in the pollinator exclusion and selfed treatment was significantly different between species $\left(\chi^{2}=\right.$ $6.5, \mathrm{p}=0.018)$, but no difference was observed to crossed treatments (i.e., intra- and inter-specific) and control $(\mathrm{p}>0.05)$.

Partial self-incompatibility was observed to $B$. pachyphylla $(\mathrm{ISI}=0.653)$ and $B$. crassifolia $($ ISI $=$ 0.405 ), with greater fruiting in autogamy (AI $B$. pachyphylla $=0.528$ and AI $B$. crassifolia $=$ 0.491). No significant difference between species in the Reproductive efficacy and Self-Incompatibility index was detected $(\mathrm{P}=0.864)$. Both species were categorized with autogamous and partially selfing, with mixed pollination system (Table 1). In addition, bidirectional interspecific cross treatment supported the reciprocal intercompatibility. Analyses of pollen tube growth (epifluorescence microscopy) corroborate the compatibility system intra- and inter-taxa (Fig. 2). In general, the pollen tube has normal morphology and similar behaviour in the stigmatic surface, in the stylar canal, ovary and micropylar canal (i.e., no callose deposition). The penetration of the micropyle canal occurs in the time-lag of 24 hours in B. crassifolia and 48 hours in $B$. pachyphylla, including intertaxa pollination (Fig. 2).

Based on dataset of mating systems to Malpighiaceae species (Table 2), variation of selfincompatibility among species and populations has been detected in Byrsonima.

In detail, ten Byrsonima species expressed 

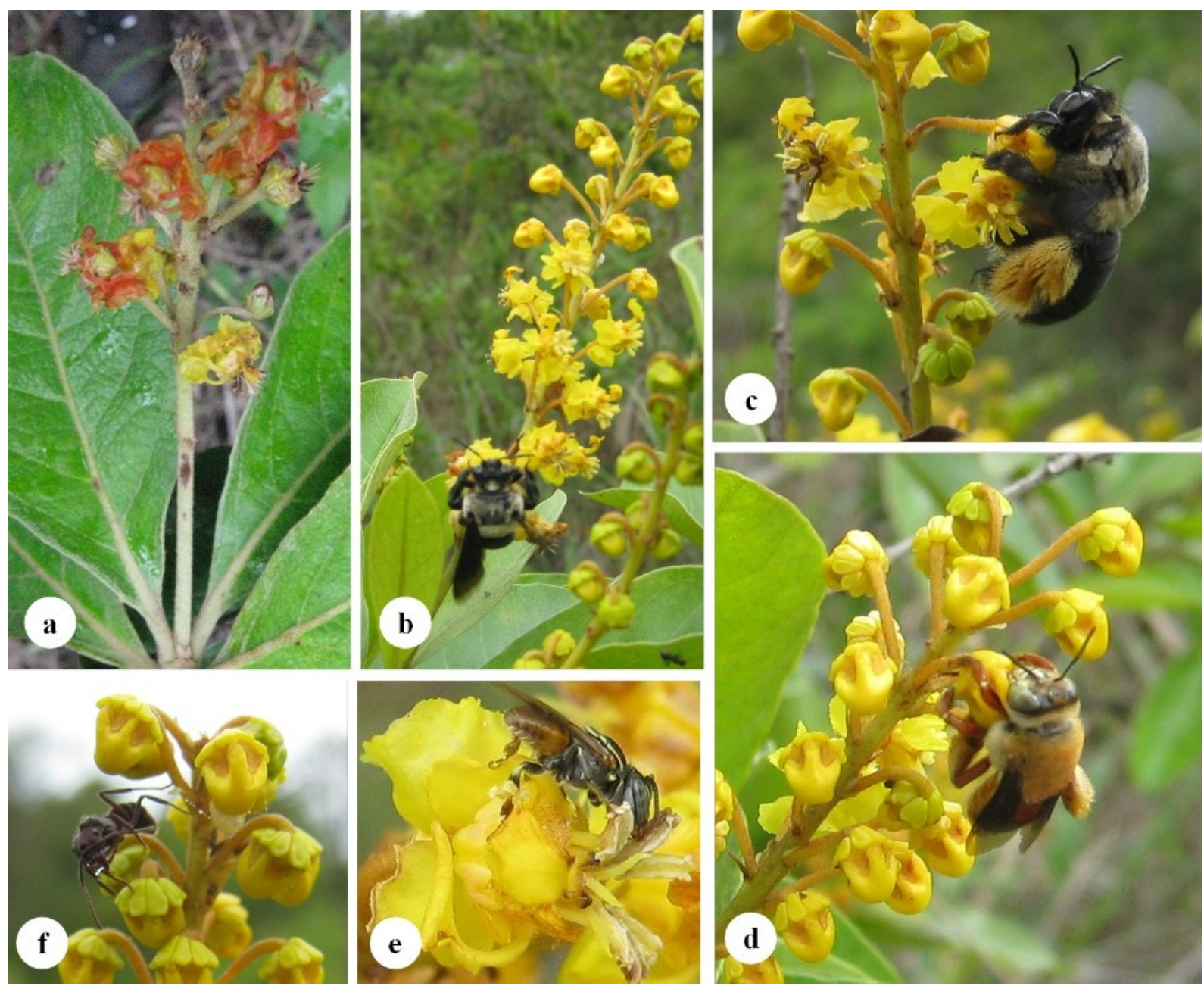

Figura 1. Detalles de la inflorescencia de (a) Byrsonima pachyphylla; (b) Byrsonima crassifolia con Epicharis (Epicharana) flava recolectando aceite en la flor y (c) yema floral; (d) inflorescencia de B. crassifolia con Centris (Centris) spilopoda recolectando aceite en yema floral; (e) inflorescencia de B. crassifolia con Paratrigona sp. colectando granos de polen; (f) Ectatomma cf. tuberculatum con una gota de agua en la mandíbula, y supuestamente recolectando pequeños artrópodos.

Figure 1. Inflorescence details of (a) Byrsonima pachyphylla; (b) Byrsonima crassifolia with Epicharis (Epicharana) flava collecting oil on the flower and (c) floral bud; (d) inflorescence of B. crassifolia with Centris (Centris) spilopoda gathering oil in floral bud; (e) inflorescence of B. crassifolia with Paratrigona sp. collecting pollen grains; (f) Ectatomma cf. tuberculatum with water droplet on the jaw, and supposedly collecting small arthropods.

\begin{tabular}{|c|c|c|c|c|}
\hline \multirow[b]{2}{*}{ Treatments } & \multicolumn{2}{|c|}{ Byrsonima pachyphylla } & \multicolumn{2}{|c|}{ Byrsonima crassifolia } \\
\hline & Fruits/Flowers $(\mathrm{N})$ & Fruit set $(\%)$ & Fruits/Flowers $(\mathrm{N})$ & Fruit set $(\%)$ \\
\hline Apomixis & $0 / 43$ & 0 & $0 / 47$ & 0 \\
\hline Autonomous (or spontaneous) self pollinaton & $26 / 69$ & 37.7 & $21 / 63$ & 33.3 \\
\hline Hand self-pollination & $21 / 45$ & 46.7 & $11 / 40$ & 27.5 \\
\hline "Geitonogamy" pollination & $18 / 40$ & 45.0 & $28 / 48$ & 58.3 \\
\hline Intraspecific cross-pollination & $35 / 49$ & 71.4 & $38 / 56$ & 67.9 \\
\hline Interspecific cross-pollination & $35 / 46$ & 76.1 & $33 / 53$ & 62.3 \\
\hline Open pollination (control not emasculation) & $50 / 68$ & 73.5 & $46 / 62$ & 74.2 \\
\hline RE (Reproductive efficacy) & 0.971 & & 0.915 & \\
\hline ISI (Self-incompatibility index) & 0.653 & & 0.405 & \\
\hline $\mathrm{Al}$ (Autogamy index) & 0.528 & & 0.491 & \\
\hline
\end{tabular}

Tabla 1. Formación de frutos en diferentes tratamientos experimentales de polinización realizados en flores de Byrsonima pachyphylla y Byrsonima crassifolia (Malpighiaceae). Se presentan el número de frutos / flores y la proporción de frutos (\%). Se muestran la eficiencia reproductiva (RE sensu Ruiz-Zapata \& Arroyo 1978), el índice de autoincompatibilidad (ISI) y el índice de autogamia AI (sensu Lloyd \& Schoen 1992). $N$ = número.

Table 1. Fruit set in different experimental pollination treatments carried out in flowers of Byrsonima pachyphylla and Byrsonima crassifolia (Malpighiaceae). The number of fruit/flower and fruiting ratio (\%) are presented. Reproductive efficiency (RE sensu Ruiz-Zapata \& Arroyo 1978), index of self-incompatibility (ISI) and autogamy index AI (sensu Lloyd \& Schoen 1992) are shown. N = number. 

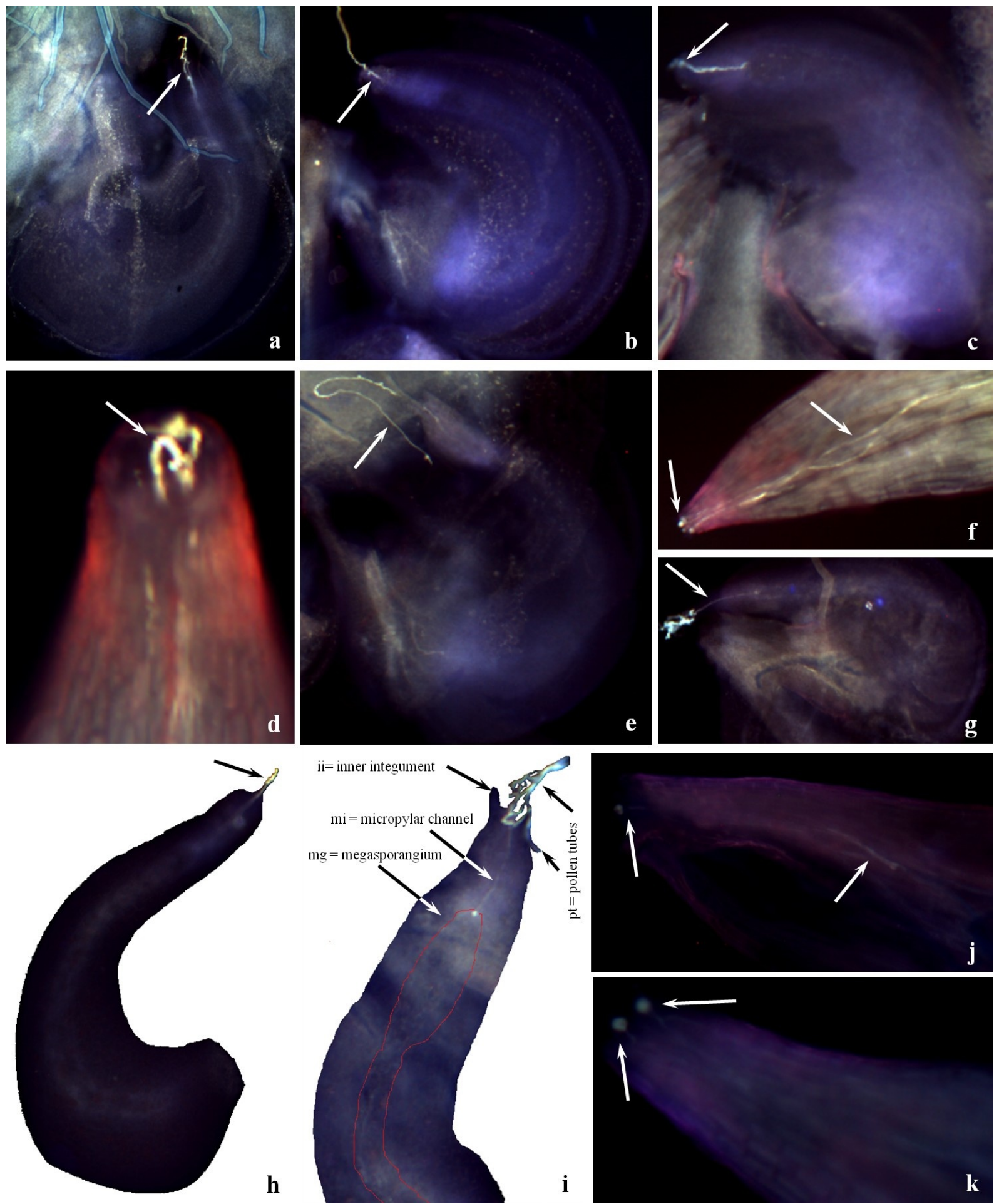

Figura 2. Tubos polínicos normales (flecha), en el ovario y el micropilo de (a) B. pachyphylla (polinización abierta); (b) B. crassifolia (autopolinización manual); (c) B. crassifolia (polinización cruzada intrapoblacional); (e) B. crassifolia (polinización cruzada interespecífica con B. pachyphylla el donante de polen); (h, i) Óvulos de B. pachyphylla (polinización cruzada interespecífica con B. crassifolia el donante de polen); y (g) B. pachyphylla (geitonogamia). Tubos polínicos normales en la superficie estigmática y el canal estigmático de: (d) $B$. crassifolia (polinización abierta); (f) polinización cruzada intrapoblacional; (j) B. pachyphylla (polinización cruzada interespecífica con donante de polen de B. crassifolia); y (k) B. crassifolia (polinización cruzada interespecífica con B. pachyphylla donante de polen).

Figure 2. Normal pollen tubes (arrow), in the ovary and micropyle of (a) B. pachyphylla (open pollination); (b) B. crassifolia (hand selfpollination); (c) B. crassifolia (intrapopulation cross-pollination); (e) B. crassifolia (interspecific cross-pollination with $B$. pachyphylla pollen donor); (h, i) Ovules of B. pachyphylla (interspecific cross-pollination with B. crassifolia pollen donor); and (g) B. pachyphylla (geitonogamy). Normal pollen tubes in stigmatic surface and stylar canal of: (d) B. crassifolia (open pollination); (f) intrapopulation crosspollination; (j) B. pachyphylla (interspecific cross-pollination with B. crassifolia pollen donor); and (k) B. crassifolia (interspecific crosspollination with $B$. pachyphylla pollen donor). 


\begin{tabular}{|c|c|c|c|c|c|c|c|c|c|c|c|c|c|c|c|}
\hline \multirow[b]{2}{*}{ Author } & \multirow[b]{2}{*}{ Year Species } & \multirow[b]{2}{*}{ RS } & \multicolumn{2}{|c|}{ Apo } & Geito & \multicolumn{2}{|c|}{ Cr_pol } & \multicolumn{2}{|c|}{ Ha_self } & \multicolumn{2}{|c|}{ Auto } & \multicolumn{2}{|c|}{ Nat_pol } & \multirow[b]{2}{*}{ ISI } & \multirow[b]{2}{*}{ RE } \\
\hline & & & $\mathrm{Fr}$ & Flo & Fr FI & $\mathrm{Fr}$ & Flo & $\mathrm{Fr}^{-}$ & Flo & $\mathrm{Fr}$ & Flo & $\mathrm{Fr}$ & Flo & & \\
\hline Sigrist et al. & 2004 Banisteriopsis adenopoda & SC & 0 & 63 & & 25 & 150 & 42 & 171 & 4 & 159 & 20 & 225 & 1.47 & 0.53 \\
\hline jigrist et al. & 2004 B. lutea & $\mathrm{SC}$ & & & & & & 2 & 36 & 0 & 87 & 1 & 54 & 3.00 & \\
\hline jigrist et al. & 2004 B. muricata & SC & & & & 16 & 42 & 2 & 117 & 0 & 66 & 3 & 108 & 0.62 & 0.07 \\
\hline Sigrist et al. & 2004 Diplopterys pubipetala & AG & 51 & 120 & & & & & & & & 26 & 144 & & \\
\hline Sigrist et al. & 2004 Dicella bracteosa & SI & & & & 2 & 38 & 0 & 45 & 0 & 42 & 0 & 41 & 0.00 & 0.00 \\
\hline tet al. & 2004 Alicia anisopetala & $\mathrm{SC}$ & & & & 6 & 183 & 2 & 261 & 2 & 117 & 8 & 198 & 0.23 & 1.23 \\
\hline et al. & $004 M$. & SI & & & & 18 & 42 & 0 & 36 & 0 & 36 & 0 & 57 & 0.00 & 0.00 \\
\hline igrist et al. & 2004 M. s & SI & & & & & & 0 & 9 & 0 & 9 & 6 & 51 & 0.00 & \\
\hline igrist et al. & 2004 Stigmaphyllon lalandianum & SI & & & & 8 & 105 & 0 & 117 & 0 & 117 & 8 & 162 & 0.00 & 0.65 \\
\hline awa & 1974 Malpighia glabra & $\mathrm{SC}$ & & & & 16 & 31 & 25 & 44 & & & 12 & 80 & 1.10 & 0.29 \\
\hline o et al. & 200650 & $S I$ & & & & 26 & 30 & 0 & 30 & 0 & 30 & 38 & 45 & 0.00 & 0.97 \\
\hline & 200 & $\mathrm{SC}$ & 0 & 15 & 1218 & 4 & 18 & 10 & 21 & 0 & 20 & 11 & 37 & 2.14 & 1.34 \\
\hline & & & 0 & 17 & 025 & 28 & 35 & 0 & 16 & 0 & 33 & 4 & 30 & 0.00 & 0.17 \\
\hline & 2 & $\mathrm{SC}$ & & & & & & 3 & 57 & 3 & 57 & 4 & 120 & 1.58 & \\
\hline & 2 & $\mathrm{SC}$ & & & & & & 17 & 132 & 17 & 132 & 96 & 102 & 0.14 & \\
\hline al. & 2 & $S I^{*}$ & 0 & 30 & 1030 & 14 & 30 & 4 & 30 & 0 & 30 & 11 & 30 & 0.29 & 0.79 \\
\hline al. & 2 & $\mathrm{SC}$ & 18 & 30 & 2730 & 20 & 30 & 15 & 30 & 7 & 30 & 18 & 30 & 0.75 & 0.90 \\
\hline t al. & 201 & SC & 1 & 18 & & 6 & 18 & 2 & 16 & 6 & 18 & 8 & 14 & 0.38 & 1.71 \\
\hline et al. & 2 & SI & & & & 103 & 314 & 5 & 314 & 0 & 736 & 161 & 370 & 0.05 & 1.33 \\
\hline et a & 201 & SI & & & & 26 & 35 & 0 & 35 & 0 & 35 & 28 & 35 & 0.00 & 1.08 \\
\hline & & $\mathrm{SI}^{*}$ & & & & 28 & 39 & 6 & 35 & 0 & 35 & 21 & 37 & 0. & 0.79 \\
\hline & & $S !$ & & & & 15 & 25 & 0 & 25 & 0 & 22 & 11 & 25 & 0.0 & 0.73 \\
\hline & 20 & SI & 3 & 112 & 3102 & 78 & 430 & 5 & 156 & 14 & 286 & 872 & 2901 & 0.18 & 1.66 \\
\hline & & S & 0 & 165 & 1115 & 4 & 119 & 5 & 118 & 5 & 159 & 42 & 145 & 1.26 & 8.62 \\
\hline & & SI & 0 & 113 & 5101 & 32 & 87 & 7 & 118 & 0 & 264 & 35 & 254 & 0.16 & 0.37 \\
\hline et al. & $2006 B$ & SI & & & & 28 & 30 & 0 & 30 & 0 & 30 & 68 & 129 & 0 & 0.56 \\
\hline$t$ al. & 200 & $\mathrm{SC}$ & & & 40100 & 64 & 100 & & & 16 & 116 & 100 & 243 & & 0.64 \\
\hline$t a$ & 2 & $\mathrm{SC}$ & 0 & 90 & 33105 & 59 & 90 & 55 & 168 & 66 & 150 & 76 & 165 & $0.5 c$ & 0.70 \\
\hline & 200 & & 0 & 15 & & & & & & 0 & 41 & 3 & 25 & & \\
\hline & 2 & SI & 0 & 16 & 420 & 20 & 27 & 2 & 16 & 0 & 31 & 18 & 32 & 0.17 & 0.76 \\
\hline & & SI & 0 & 28 & 124 & 13 & 30 & 0 & 17 & 0 & 28 & 20 & 78 & 0.00 & 0.59 \\
\hline & & SC & & & 820 & 7 & 20 & 4 & 20 & 1 & 20 & 17 & 20 & 0.57 & 2.43 \\
\hline an & & SC & & & & 58 & 80 & 48 & 149 & & & 102 & 406 & 0.44 & 0.35 \\
\hline & 2 & SI & 0 & 13 & $\begin{array}{ll}0 & 14\end{array}$ & 14 & 28 & 0 & 12 & 0 & 16 & 33 & 275 & 0 & 0.24 \\
\hline Dli & 20 & $\mathrm{SC}$ & 0 & 41 & & 14 & 54 & 12 & 45 & 0 & 45 & 19 & 43 & 1.03 & 1.70 \\
\hline & 201 & & & & & 0.72 & & & & 0.54 & & & & & \\
\hline Barrc & 199 & & & & & 0.337 & & & & 0.105 & & & & & \\
\hline Barros & 1992 B. C & & 80 & 100 & & & & & & & & & & & \\
\hline Barros & 1992 B. la & & 57.6 & 72 & & & & & & & & & & & \\
\hline & 200 & $\mathrm{SC}$ & & & & 32 & 40 & 9 & 40 & 0 & 40 & 30 & 40 & 0.2 & 0.94 \\
\hline al. & & $\mathrm{SI}$ & 0 & 30 & & 28 & 30 & 0 & 30 & 0 & 30 & 68 & 129 & 0.00 & 0.56 \\
\hline & מ & $\mathrm{SC}$ & 0 & 30 & & 9 & 30 & 4 & 30 & 3 & 30 & 11 & 30 & 0.44 & 1.22 \\
\hline Matallana et al & 2016 B. sericea & SI & & & & & ifluo & esce & ence & icro & opy & & & & \\
\hline
\end{tabular}

Tabla 2. Resumen de los sistemas reproductivos en los géneros Malphigiaceae en el Neotrópico. Apo: apomixis; Geito: polinización "geitonogamia"; Cr_pol: polinización cruzada intraespecífica; Ha_self: autopolinización manual; Auto: autopolinización autónoma (o espontánea); Nat: polinización natural o abierta. ISI= índice de autoincompatibilidad; RE= eficacia reproductiva (Zapata y Arroyo 1978). RS: sistema reproductivo; $\mathrm{SC}=$ autocompatible; $\mathrm{SI}=$ autoincompatible; $\mathrm{AG}=$ agamospermia; $*$ = facultativo.

Table 2. Summary of the reproductive systems in Malphigiaceae genera in the Neotropics. Apo: Apomixis; Geito: "Geitonogamy" pollination; Cr_pol: Intraspecific cross-pollination; Ha_self; Hand self-pollination; Auto: Autonomous (or spontaneous) self pollinaton; Nat: Natural or open pollination. ISI = Self-incompatibility index and RE $=$ Reproductive efficacy (from Zapata and Arroyo, 1978). RS: Reproductive system; $\mathrm{SC}=$ self-compatible, $\mathrm{SI}=$ self-incompatible, $\mathrm{AG}=$ agamospermous, $*$ =Facultative.

self-incompatibility, and seven species were selfcompatible. In addition, agamospermy was recognized only for Diplopterys pubipetala (A.Juss.) W.R.Anderson \& C.Davis among all 30 Malpighiaceae species. Large spectrum to Self-incompatibility (ISI) and Reproductive efficacy (RE) index was observed to Malpighiaceae (maximum and minimum; average \pm Standard Deviation: ISI, 0.00 and $3.00 ; 0.49 \pm 0.67$ and RE, 0.00 and 8.62 ; $1.06 \pm 1.40)$.

\section{Discussion}

The aggregation of hermaphrodite flowers in Byrsonima spp. inflorescences might favour self-pollination mechanisms in both senses: intra-floral interference and geitonogamy (Gibbs 2014). In this case, pre-zygotic mechanisms to prevent selfing have been commonly found in Malpighiaceae (e.g., herkogamy, protogyny, stigmatic cuticle, and distinct types of self-incompatibility mecha- 
nisms) (Sigrist \& Sazima 2004, Downing \& Liu 2013, Balestra et al. 2014). On the other hand, some species of Malpighiaceae show fruit formation by spontaneous treatment, as for example in Alicia anisopetala (A.Juss.) W.R.Anderson (2\%), Tetrapterys guilleminiana A.Juss. (5\%), Tetrapterys phlomoides (Spreng.) Nied. (13\%) (Sigrist \& Sazima 2004), and Byrsonima species (44\% in B. coccolobifolia, $5 \%$ in B. crassifolia, $23 \%$ in $B$. rotunda, $5 \%$ in $B$. cydoniifolia) (Benezar \& Pessoni 2006, Benezar 2006, Mendes et al. 2011, Sazan et al. 2014). In addition, values of fruiting by hand self-pollination, observed here to Byrsonima pachyphylla (38\%) and B. crassifolia (33\%), corroborated the recurrence of selfing on the Malpighiaceae and Byrsonima. This event could be attributed to delayed movement presented by the style towards the anthers (e.g., Benezar \& Pessoni 2006) or homogamy in pre-anthesis, that is, presence of open anthers and receptive stigmas in the pre-anthesis bud, when anthers and stigmas are close (see Barros 1992), a possible strategy to facilitate the process of self-pollination even in the absence of pollinators. In addition, in some Byrsonima species, the stigmatic cuticle prevents water loss in xeric systems and adhesion of pollen grains to the stigma (i.e., mechanical system to prevent selfing), reinforcing the importance of pollinators in the rupture of the stigmatic cuticle (Sigrist 2004, Downing \& Liu 2013).

Delayed selfing strategies are understood as a mechanism to maintain the floral traits promoting outcrossing (Lepers et al. 2014). On the other hand, the aggregation of hermaphrodite flowers in inflorescences of Byrsonima increases the "geitonogamy" pollination (de Jong et al. 1993, Gibbs 2014). Byrsonima pachyphylla featured similar fruit:flower ratio between "geitonogamy" and hand self-pollination treatments, differently to $B$. crassifolia, with more $47 \%$ of geitonogamous fruits. These discrepancies may be linked to higher plant attractiveness of $B$. crassifolia due to mass flowering ensured by inflorescence architecture with numerous flowers. On the other hand, $B$. pachyphylla is a tree, with inflorescences more distant from each other, modeling the bionomy of floral visitors / pollinators to spend more energy on intra-plant flights/foraging, discouraging the "geitonogamy" pollination in this species. In general, self-compatible species with limited ability of selfing (e.g., stigmatic cuticle, delayed movement of stylet towards the anthers) could maintain a balance between selfing and outcrossing rates in pollinator-limited environments or seasonally floating (e.g., Karrenberg \& Jensen 2012, Voillemont \& Pannell 2017, Bartoš et al. 2020).

Distinct fruit production from selfing and crossing treatments in Byrsonima and other Malpighiaceae genera (Alicia W.R.Anderson, Banisteriopsis C.B.Rob., Diplopterys A.Juss., Galphimia Cav., Heteropterys Kunth, Malpighia L. Mascagnia (Bertero ex DC.) Colla, Peixotoa A.Juss., and TetrapterysCav.) (Bawa 1974, Barros 1992, Sigrist \& Sazima 2004) is not totally supported by a theoretical base of subsequent events of pistil rejection (i.e., late-acting self-incompatibility systems with early acting inbreeding depression due to deleterious recessive alleles; see Gibbs 2014). On the other hand, homomorphic selfincompatibility systems are widespread on Malpighiaceae, with diversification of reproductive systems within and among genera of the family (Anderson 1980, Barros 1992, Sigrist \& Sazima 2004, Benezar \& Pessoni 2006, Costa et al. 2006, Bezerra et al. 2009, Sazan et al. 2014). For example, Byrsonima presents a wide range of mating systems: self-incompatible (e.g., $B$. sericea) (Costa et al. 2006), partially self-incompatible (e.g., B. umbellata) (Mendes et al. 2011), self-compatible (e.g., B. intermedia) (Oliveira et al. 2007), and rarely apomixis (e.g., Diplopterys pubipetala, B. cydoniifolia) (Sigrist \& Sazima 2004, Sazan et al. 2014). Empirical data support the recurrence of non-obligatory xenogamous or mixed reproductive system and levels of selfincompatibility in the Byrsonima. In addition, the study area is an urban forest fragment, and selfcompatible phenotypes tend to be selected when there is a shortage of pollinators, in disturbed environments or subject to anthropization.

Different levels of incompatibility has been reported to $B$. intermedia populations (e.g., ISI= 1.0, Oliveira et al. 2007; ISI=0.16, Balestra et al. 2014). For $B$. pachyphylla (ISI $=0.65$ ) and $B$. crassifolia (ISI $=0.45$ ) populations in the present study could be considered self-compatible or with partial self-incompatibility, without pollen tube reactions in all levels evaluated (i.e., stigmatic surface, pistil canal, ovary and micropyle channel), but with higher fruit:flower ratio in xenogamy. Similarly, two populations of $B$. crassifolia (ISI= 0.44, Bawa 1974; ISI=0.57 Benezar 2006) can be considered self-compatible, and with partial self-incompatibility (ISI $=0.28$, Pereira \& 
Freitas 2002). Conversely, B. pachyphylla was also considered self-incompatible (ISI $=0$, VilasBoas et al. 2013). This population variability in the levels of incompatibility can be attributed to numerous factors (e.g., differential rates in pollinator-limited environments, variation in the herkogamy or dichogamy levels, and efficiency of stigmatic cuticle in unpredictable environments). Unfortunately, I do not know of the existence of studies evaluating population variability in these traits.

Our hypothesis of inter-taxa incompatibility between two sympatric populations of $B$. pachyphylla and $B$. crassifolia needs more information to corroborate. Fruiting in the manual cross-pollination and pollen tubes grew analysis by fluorescence microscopy techniques reinforces the evidence for the absence of pre-zygotic barriers and reciprocal intercompatibility, although individuals with intermediate morphology were not identified in situ. In Malpighiaceae, the similarities in flower morphology, pollinator-dependency and oil-collecting bees guild (e.g., Centridini, Tapinotaspidini tribes) have been identified as the main factors to fixation of a homomorphic self-incompatibility system (Sigrist \& Sazima 2004). However, high levels of compatibility observed in the populations studied here, indicate that pre-zygotic barriers between $B$. pachyphylla and B. crassifolia are weak or absent, making hybridization likely to occur under natural conditions. In spite of the apparent success of fruit formation from inter-taxa pollinations, hybrids are not distinguished. Similar approaches in Chamaecrista desvauxii (Collad.) Killip. (Caesapinioideae) varieties demonstrated that death of the embryo or the endosperm in the seed level is the principal post-zygotic isolation mechanism (Costa et al. 2007). Unfortunately, seed germination was not evaluated in present research. Additionally, I do not know any other study reporting the possibility of reciprocal intercompatibility for Byrsonima species.

All attributes of B. pachyphylla and B. crassifolia (i.e., syntopic, sharing oil-collecting bees, floral monomorphism, selfing and inter-taxa pollination) reinforce the failure of pre-zygotic mechanisms. Late-acting self-incompatibility (i.e., level of ovary and microphillar canal) and post-zygotic rejections (i.e., abscission of selfed pistils or fruits) are unlikely by the absence of abnormal pollen tubes in the ovaries and higher fruiting taxa ( $>70 \%$ fruit:flower ratio in intra- and inter-taxa pollination). In this scenario, I assume that $B$. and $B$. crassifolia are non-obligatory xenogamous but with high efficacy of oil-collecting bees to pollen transfer. Finally, the absence of morphological variants or hybrids in natural populations supports the hypothesis of inbreeding depression (i.e., embryo or endosperm death in the seed level). Much of this evidence is circumstantial, and at this point I suggest employing seed germination experiments and molecular approach in the offspring to investigate inbreeding depression, hybridization and introgression events in synchronopatric Byrsonima species.

\section{Acknowledgments}

I thank Ari T. Oliveira-Filho for plant identification, Favízia Freitas de Oliveira and Antônio Freire de Carvalho Filho for bee identifications, Jorge Luiz P. de Souza for ant identification, staff of Ecological Station - UFMG for permission to collect data, and Eduardo L. Borba for permission to use epifluorescence microscope.

Funding FMH received a fellowship from Conselho Nacional de Desenvolvimento Científico e Tecnológico (grants 301373/2020-5). I would like to thank the reviewers again for his/her comments and suggestions, which have further contributed to improve the manuscript.

\section{References}

Aguiar AJC, Melo GAR, Vasconcelos TNC, Gonçalves RB, Giugliano L \& Martins AC. 2020. Biogeography and early diversification of Tapinotaspidini oil-bees support presence of Paleocene savannas in South America, Molecular Phylogenetics and Evolution 143: 106692. https://dx.doi.org/10.1016/j.ympev. 2019.106692.

Alvares CA, Stape, JL, Sentelhas PC, Gonçalves JLM \& Sparovek G. 2013. Köppen's climate classification map for Brazil. Meteorologische Zeitschrift, 22: 711728. https://dx.doi.org/10.1127/0941-2948/2013/05 07.

Amorim ME \& de Marco PB. 2011. Pollination of Byrsonima coccolobifolia: short-distance isolation and possible causes for low fruit production. Brazilian Journal of Biology 71: 709-717. https://dx.doi.org/10.1590/S1519-698420110004000 16.

Anderson WR. 1979. Floral conservatism in neotropical Malpighiaceae. Biotropica 11: 219-223. https://dx. doi.org/10.2307/2388042.

Anderson WR. 1980. Cryptic self-fertilization in the Malpighiaceae. Science 207: 892-893. https://dx.doi. 
org/10.1126/science.207.4433.892.

Balestra CL, Fachardo ALS, Soares MP, Reys P \& Guimarães F. 2014. Biologia reprodutiva e polinização de duas espécies de Byrsonima Kunth num fragmento de Cerrado no Brasil Central. Revista de Biociências 20: 71-81.

Barros MAGE. 1992. Fenologia da floração, estratégias reprodutivas e polinização de espécies simpátricas do gênero Byrsonima Rich (Malpighiaceae). Brazilian Journal of Biology 52: 343-353.

Bartoš $M$, Janeček Š, Janečková $P$, Padyšáková $E$, Tropek R, Götzenberger L, Jersáková J. 2020. Selfcompatibility and autonomous selfing of plants in meadow communities. Plant Biology 22: 120-128. https://dx.doi.org/10.1111/plb.13049.

Bawa KS. 1974. Breeding systems of tree species of a lowland community. Evolution 28: 85-92. https:// dx.doi.org/10.2307/2407241.

Benezar RMC. 2006. Sistema reprodutivo e diversidade genética de populações naturais de muricizeiros (Byrsonima crassifolia L. Kunth) nas savanas de Roraima. Dissertation of master.

Benezar RMC \& Pessoni LA. 2006. Biologia floral e sistema reprodutivo de Byrsonima coccolobifolia (Kunth) em uma savana amazônica. Acta Amazônica 36: 159-168. https://doi.org/10.1590/ S0044-59672006000200005.

Bezerra ES, Lopes AV \& Machado IC. 2009. Biologia reprodutiva de Byrsonima gardnerana A. Juss. (Malpighiaceae) e interações com abelhas Centris (Centridini) no Nordeste do Brasil. Revista Brasileira de Botânica 32: 95-108. https://doi.org/10.1590/ S0100-84042009000100010.

Buchmann SL. 1987. The ecology of oil flowers and their bees. Annual Review of Ecology and Systematics 18: 343-369. https://doi.org/10.1146/ annurev.es.18.110187.002015

Costa CBN, Lambert SM, Borba EL \& Queiroz LP. 2007. Post-zygotic reproductive isolation between sympatric taxa in the Chamaecrista desvauxii Complex (Leguminosae-Caesalpinioideae). Annals of Botany 99: 625-635. https://dx.doi.org/10. 1093/aob/mcm012

Costa CBN, Costa JAS \& Ramalho M. 2006. Biologia reprodutiva de espécies simpátricas de Malpighiaceae em dunas costeiras da Bahia, Brasil. Revista Brasileira de Botânica 29: 103-114. https://dx.doi.org/10.1590/S0100-84042006000100 010.

Cronquist A. 1981. An integrated system of classification of flowering plants. New York: Columbia University.

Davis CC \& Anderson WR. 2010. A complete generic phylogeny of Malpighiaceae inferred from nucleotide sequence data and morphology. American Journal of Botany 97: 2031-2048. https://dx.doi.org/110.3732/ ajb.1000146.

de Jong TJ, Waser NM \& Klinkhamer PGL. 1993. Geitonogamy: the neglected side of selfing. Trends in Ecology and Evolution 9: 321-325. https://dx.doi. org/10.1016/0169-5347(93)90239-L.

Downing JL \& Liu H. 2013. Self-incompatibility in Byrsonima lucida (Malpighiaceae), a threatened pine rockland specialist. Castanea 78: 95-102. https://dx. doi.org/10.2179/12-031.

Dunley BS, Freitas L \& Galetto L. 2009. Reproduction of Byrsonima sericea (Malpighiaceae) in restinga fragmented habitats in southeastern Brazil. Biotropica 41: 692-699. https://dx.doi.org/10.1111/j. 1744-7429.2009.00524.x.

Flora do Brasil 2020. Jardim Botânico do Rio de Janeiro. Available in: http://floradobrasil.jbrj.gov.br/. (Acessed at 29-X-2021).

Gibbs PE. 2014. Late-acting self-incompatibility - the pariah breeding system in flowering plants. New Phytologist 203: 717-734. https://dx.doi.org/10.1111/ nph.12874.

Gottsberger G. 1986. Some pollination strategies in neotropical savannas and forests. Plant Systematics and Evolution 152: 29-45. https://dx.doi.org/10.1007/ BF00985349.

Igic B, Lande R \& Kohn JR. 2008. Loss of selfincompatibility and its evolutionary consequences. International Journal of Plant Science 169: 93-104. https://dx.doi.org/10.1086/523362.

Inouye DW. 1980. The terminology of floral larceny. Ecology 61: 1251-1253. https://dx.doi.org/10.2307/ 1936841.

Karrenberg S \& Jensen K. 2012. Effects of pollination and pollen source on the seed set of Pedicularis palustris. Folia Geobotanica 35: 191-202. https://dx. doi.org/10.1007/BF02803097.

Khan G, Franco FF, Silva GAR, Bombonato JR, Machado Alonso DP, Ribolla PEM, ... Moraes EM (2020) Maintaining genetic integrity with high promiscuity: Frequent hybridization with low introgression in multiple hybrid zones of Melocactus (Cactaceae). Molecular Phylogenetics and Evolution 142:106642. https://dx.doi.org/10.1016/j.ympev.20 19.106642.

Lepers C, Dufay M \& Billiard S. 2014. How does pollination mutualism affect the evolution of prior self-fertilization? A model. Evolution 68: 3581-3598. https://dx.doi.org/10.1111/evo.12533.

Lloyd DG \& Schoen DJ. 1992. Self- and crossfertilization in plants. I. Functional dimensions. International Journal of Plant Science 153: 358-369.

Machado IS, Lopes AV \& Sazima. 2006. Plant sexual systems and a review of the breeding system studies in the caatinga, a Brazilian tropical dry forest. Annals of Botany 97: 277-287. https:// dx.doi.org/10.1093/aob/mcj029.

Martin FW. 1959. Staining and observing pollen tubes in the style by means of florescence. Stain Technology 34: 125-128. https://dx.doi.org/10.3109/105202959 09114663.

Matallana G, Marcarini L \& Menezes LFT. 2016. Crescimento de tubos polínicos e local de incompatibilidade em Byrsonima sericea DC (Malpighiaceae). Boletim do Museo de Biologia Mello Leitão 38: 59-71.

Melo MS, Oliveira DE \& Franceschinelli EV. 2014. Density and fertility of Byrsonima pachyphylla A. Juss. (Malpighiaceae) in small fragments of the Brazilian Cerrado. Acta Botânica Brasilica 28: 259- 
265. https://dx.doi.org/10.1590/S0102-3306201400 $\underline{0200012}$.

Mendes FN, Rego MMC, \&Albuquerque PMC. 2011. Fenologia e biologia reprodutiva de duas espécies de Byrsonima Rich. (Malpighiaceae) em área de Cerrado no Nordeste do Brasil. Biota Neotropica 11: 103-115. https://dx.doi.org/10.1590/S1676-0603201 1000400011.

Neff JL \& Simpson BB. 1981. Oil-collecting structures in the Anthophoridae (Hymenoptera): morphology, function, and use in systematics. Journal of the Kansas Entomology Society 54: 95-123.

Oliveira MIB, Polido CD, Costa LC \& Fava WS. 2007. Sistema reprodutivo e polinização de Byrsonima intermedia A. Juss. (Malpighiaceae) em Mato Grosso do Sul, Brasil. Revista Brasileira de Biociências 5: 756-758.

Peixoto KS, Almeida DS, Capuzzo JP, Elias MAS, Melo MS, Morais RJ \& Ribeiro MN. 2011. Sistema de polinização e reprodução do muricizeiro Byrsonima crassa (Malpighiaceae). Revista Eletrônica Interdisciplinar - Univar 7: 17-21. Available in http://revista.univar.edu.br/Interdisciplinar (Acessed at 29-X-2021).

Pereira JOP \& Freitas BM. 2002. Estudo da biologia floral e requerimentos de polinização do muricizeiro (Byrsonima crassifolia L.). Revista de Ciências Agronômicas 33: 5-12.

Possobom CCF \& Machado SR. 2018. Elaiophores in three Neotropical Malpighiaceae species: a comparative study. Plant Systematics and Evolution 304: 15. https://dx.doi.org/10.1007/s00606-017-1443 -6.

$R$ Core Team 2020: A language and environment for statistical com-puting. R Foundation for Statistical Computing, Vienna, Austria.

Ruiz TZ \& Arroyo MTK. 1978. Plant reproductive ecology of a secondary deciduous tropical forest in
Venezuela. Biotropica 10: 221-230. https://dx.doi. org/10.2307/2387907.

Sazan MS, Bezerra ADM \& Freitas BM. 2014. Oil collecting bees and Byrsonima cydoniifolia A. Juss. (Malpighiaceae) interactions: the prevalence of longdistance crosspollination driving reproductive success. Anais da Academia Brasilera de Ciências 86: 347-358. https://dx.doi.org/10.1590/0001-3765 201420130049.

Sigrist MR \& Sazima M. 2004. Pollination and reproductive biology of twelve species of neotropical Malpighiaceae: Stigma morphology and its implications for the breeding systems. Annals Botany 94: 33-41. https://dx.doi.org/10.1093/aob/ mch108.

Teixeira LAG \& Machado IC. 2000. Sistema de polinização e reprodução de Byrsonima sericea DC (Malpighiaceae). Acta Botânica Brasílica 14: 347357. https://dx.doi.org/10.1590/S0102-3306200000 0300011.

Vilas-Boas JCV, Fava WS, Larocac S \& Sigrist MR. 2013. Two sympatric Byrsonima species (Malpighiaceae) differ in phenological and reproductive patterns. Flora 208: 360-369. http://dx.doi.org/10. 1016/j.flora.2013.05.003.

Vogel S. 1974. Ölblumen und ölsammelnde bienen. Tropische und Subtropische Pflanzenwelt 7: 285547.

Vogel S. 1988. Die ölblumen-symbiosen - parallelismus und andere aspekte ihrer entwicklung in raum und Zeit. Zeitschrift fur zoologische Systematik und Evolutionsforschung 26: 341-362. https://dx.doi.org/ 10.1111/j.1439-0469.1988.tb00322.x.

Voillemot M \& Pannell JR. 2017. Inbreeding depression is high in a self-incompatible perennial herb population but absent in a self-compatible population showing mixed mating. Ecology and Evolution 7: 8535-8544. http://dx.doi.org/10.1002/ece3.3354. 